\title{
ДОСЛІДЖЕННЯ НАВЧАЛЬНОЇ МОТИВАЦІЇ У СТУДЕНТІВ ПЕРШОГО КУРСУ ТЕРНОПІЛЬСЬКОГО ДЕРЖАВНОГО МЕДИЧНОГО УНІВЕРСИТЕТУ ІМЕНІ І. Я. ГОРБАЧЕВСЬКОГО
}

\author{
Н. І. Бурмас, Л. А. Бойко, І. Р. Бекус, М. В. Кирилів \\ ДВНЗ “Тернопільський державний медичний університет \\ імені І. Я. Горбачевського МОЗ Украӥни”
}

\section{THE RESEARCH OF LEARNING MOTIVATION IN THE FIRST YEAR STUDENTS OF I. YA. HORBACHEVSKY TERNOPIL STATE MEDICAL UNIVERSITY}

\author{
N. I. Burmas, L. A. Boyko, I. R. Bekus, M. V. Kyryliv \\ I. Horbachevsky Ternopil State Medical University
}

\begin{abstract}
У статті проведено діагностику навчальної мотивації студентів першого курсу медичного факультету методом анкетування. Отримані дані розкривають структуру мотивації першокурсників і свідчать про необхідність втручання у процес ії формування. Домінуючими для студентів медичного факультету виявилися професійні мотиви. Результати дослідження показали різні мотиви студентів до навчання, що потребує організаційних та виховних зусиль професорсько-викладацького складу для компетентного впливу на підвищення навчальної мотивації.

The article adduces the diagnostics of learning motivation of the first year students of medical faculty by the questioning method. The obtained data revealed the structure of motivation of the freshmen and indicated the need for intervention in the process of its formation. The dominant for medical students were professional reasons. The results of research showed different motives of students at the teaching that need of organizational and educational efforts of the professor-teaching staff for the competent effect on increasing of the learning motivation.
\end{abstract}

Вступ. Сучасна система вищої педагогічної освіти розвивається та функціонує у нових політичних та соціально-економічних умовах, які визначають не лише шляхи та напрями ії розвитку, але й безпосередньо пов'язані з цими проблемами. Вдосконалення підготовки студентів в умовах вищого навчального медичного закладу зумовлене багатьма чинниками, серед яких важливим $€$ мотивація їхньої навчально-пізнавальної діяльності. 3 урахуванням цього однією з актуальних проблем сучасної вищої освіти є побудова такого навчально-виховного процесу, який зможе бути основою для формування та розвитку мотиваційної сфери студентів.

Складність проблеми мотивації студентів до навчання обумовлює множинність розуміння її суті, природи, структури, функцій. Для початку потрібно визначитись 3 поняттям “мотивація”. До поняття “мотивація” входить цілий комплекс аспектів, під якими розуміється система спонукань: мотиви, по-

() Н. І. Бурмас, Л. А. Бойко, І. Р. Бекус, М. В. Кирилів треби, інтереси, прагнення, цілі, потяги, мотиваційні установки (диспрозії), ідеали. Мотивація - опосередкована процесом її відображення суб'єктивна детермінація поведінки людини світом. Головною характеристикою мотиваційної сфери $є$ ієрархія мотивів, що дозволяє виявити особистісний зміст діяльності для будь-якої людини [1].

Отже, мотивацією для студента виступає бажання вчитися не тільки заради досягнення академічної мети, але і для професійного росту. Ступінь навчальної активності студента $є$ наслідком сильної або слабкої мотивації навчання. Можна сказати, що мотиви учіння - це активізуюча сила, одна 3 основних умов навчальної діяльності. У загальному вигляді проблема мотивації навчання є проблемою причин, які визначають різні форми виявлення активності тих, хто навчається.

Основна частина. Беззаперечним $є$ надзвичайно великий вплив сили навчальної мотивації та ї̈ структури на успішність навчальної діяльності. 
Численні дослідження встановлюють наявність залежності ефективності діяльності від сили мотивації: що вища сила мотивації, то вища результативність діяльності; саме наявність у студентів сформованої професійної мотивації відрізняє сильних студентів від невстигаючих [2].

3 огляду на це можна стверджувати, що формування позитивної мотивації студентів до обраної майбутньої професії виступає одним із провідних факторів підвищення рівня якості їхньої навчальної діяльності: формування інтересу до змісту обраної професійної діяльності, переважання позитивного ставлення до праці в галузі професійної діяльності.

Згідно з літературними джерелами, виділяють перелік мотивів навчальної діяльності: широкі соціальні мотиви; пізнавальні мотиви, що спричинені самою навчальною діяльністю; комунікативні мотиви, мотив участі в навчальному процесі; мотиви соціальної ідентифікації (з батьками, однолітками, педагогами); мотиви особистісного розвитку (професійного самовизначення, матеріального благополуччя); мотиви успіху (самоствердження, самовираження); мотиви уникнення неприємностей [3].

Очевидно, що формування у студентів саме внутрішньої мотивації є невід’ємним елементом процесу адаптації до професійного навчання у ВНЗ і безпосередньо впливає на процес подальшого професійного становлення майбутніх фахівців. Саме внутрішні мотиви пов'язані із прагненням особистості до самоповаги, з потребою в самореалізації, і це вимагає цілеспрямованого формування тих особистісних якостей, які необхідні для успішного виконання майбутньої професійної діяльності. Це надасть майбутнім лікарям можливість розкрити особистісний потенціал, досягти професійного та творчого зростання.

На користь актуальності дослідження свідчить приділення належної уваги з боку держави проблемам мотивації студентів у вищій школі з метою реалізації ідей освіти для сталого розвитку суспільства. Зокрема, 1 липня 2014 р. було прийнято Закон України “Про вищу освіту” [4].

Проблему мотивації навчальної діяльності студентів розглядали такі зарубіжні і вітчизняні учені, як: Л. Божович, Л. Виготський, В. Вилюнас, І. Васильєв, М. Боришевський, Б. Додонов, О. Донцов, О. Дусавицький, Є. Ільїн, О. Коваленко, Г. Костюк, О. Леонтьєв, Й. Лінгардт, С. Максименко, А. Маркова, А. Маслоу, В. М'ясищев, В. Семиченко, О. Скрипченко, Д. Узнадзе, Х. Хекхаузен, П. Якобсон та ін.

Метою нашого дослідження було вивчення особливостей структури навчальної мотивації студентів першого курсу медичного факультету Тернопільського державного медичного університету імені I. Я. Горбачевського. У процесі анкетування було опитано 200 студентів. Для досягнення мети дослідження були використані такі психодіагностичні методи: дослідження домінуючої мотивації (методика “Дослідження мотивації на досягнення успіху” Т. Елерса) [5], визначення структури навчальної мотивації (методика “Мотивація навчальної діяльності” А. О. Реана, В. А. Якуніна) [6]. Аналіз результатів здійснювався у відсотковому відношенні, де 100 \%кількість студентів, що брали участь у дослідженні.

Отримані дані розкривають структуру мотивації студентів-першокурсників і свідчать про необхідність втручання у процес її формування, зокрема формування позитивних внутрішніх мотивів. Домінуючими для студентів медичного факультету виявилися професійні мотиви: 82 \% осіб, від загальної кількості опитаних, виявили бажання повністю використовувати свої задатки, здібності та схильності до обраної професії, бути фахівцем та забезпечувати успішність майбутньої професійної діяльності, а в подальшому стати висококваліфікованими лікарями. Проте оволодівати професійними знаннями відповідно до обраної спеціальності мають бажання тільки 70 \% з них.

Згідно з результатами дослідження на другому місці структури навчальної мотивації першокурсників є соціальні мотиви: 80 \% студентів вважають, що отримані знання дадуть змогу досягти усього необхідного, і від цього залежить рівень їх майбутніх статків та подальше професійне зростання. Займатися творчою діяльністю (мотиви творчої самореалізації) та розкривати свої творчі здібності виявили бажання 78 \% студентів, але тільки у 50 \% першокурсників університету, які брали участь у дослідженні, відсутні психологічні бар'єри для повного розкриття своїх інтелектуальних та творчих можливостей.

Навчальна діяльність студентів - це не просто засіб для формування професійної компетентності, але й задоволення пізнавальної потреби. У спілкуванні відбувається обмін інформацією, знаннями, способами дій, почуттями і настроями, що приводить до підвищення рівня інформованості учасників спільної діяльності. В умовах спілкування інтерес виникає частіше спочатку до ситуації взаємодії або до самого процесу спілкування з партнером, а вже потім ативізується власне пізнавальна мотивація. Комунікативна природа навчальної діяльності повинна сприяти активізації пізнавальної активності та задоволенню пізнавальних потреб студентів. Комунікативні мотиви у студентів першого курсу 
складають 76 \%, що свідчить про прагнення до партнерського спілкування з учасниками навчальної діяльності, налагодження продуктивної міжособистісної взаємодії.

П’ятим фактором мотивації навчання для майбутніх лікарів є навчально-пізнавальні мотиви: 70 \% першокурсників навчаються тільки тому, що їм просто подобається вчитися. Вони бажають успішно навчатися і складати іспити на “добре” та “відмінно”, а також вважають, що будь-які знання знадобляться у майбутній професії, і в подальшому планують зайнятися науковою діяльністю за фахом.

За результатами анкетування встановлено, що на останньому місці структури мотивів є мотиви престижності обраної професії, а не оволодіння професійними навичками. Вже на першому курсі 66 \% опитаних студентів бажають формально засвоювати знання та знаходити обхідні шляхи, щоб складати екзамени для отримання диплома.

Отже, отримані дані можуть свідчити, що на час проведення анкетування серед студентів 1-го курсу медичного факультету спостерігається домінування професійних мотивів навчання у вузі. Але на даному факультеті також були виявлені студенти, яких у навчанні спрямовують мотив “уникання” 50 \% (прагнення в будь-якій ситуації діяти так, щоб уникнути невдачі, - особливо якщо результати діяльності сприймаються і оцінюються іншими людьми). Отже, необхідно звернути увагу на формування мотивів, що сприяють професійно-спрямованому навчанню студентів, що цього потребують, шляхом роз'яснення необхідності отримання, в першу чергу, міцних та глибоких професійних знань, умінь та навичок.

Мотивація досягнення характеризується прагненням людини до успіхів у різних видах діяльності й униканням невдач. Проявляється у здатності до конкуренції, у прагненні до досконалості, у бажанні напруженої роботи. В основі мотивації досягнень ле-

\section{Список літератури}

1. Заброцький М. М. Педагогічна психологія / М. М. Заброцький. - К., 2000. - 356 с.

2. Прудська О. Дослідження факторів психологічної адаптації студентів-першокурсників до навчально-професійної діяльності / О. Прудська // Освіта регіону. 2011. - № 3. - С. 375-381.

3. Малінка О. О. Психологічні проблеми мотивації навчально-професійної діяльності студентів у сучасних умовах [Електронний ресурс] / О. О. Малінка. - Режим доступу : www.psyh.kiev.ua.

4. Закон України “Про вищу освіту” від 01.07.2014 p. № 1556-VII. - Режим доступу : http://zakon2.rada.gov.ua/ laws/show/1556-18. жать емоційні переживання, пов'язані із соціальним прийняттям успіхів, які досягаються особистістю. За даними літератури, основними чинниками, що впливають на формування позитивної стійкої мотивації до навчальної діяльності, є: зміст навчального матеріалу; організація навчальної діяльності; колективні форми навчальної діяльності; оцінка навчальної діяльності; стиль педагогічної діяльності [7].

За результатами дослідження домінуючої мотивації у першокурсників було виявлено, що показники розділилися таким чином: 52 \% студентів мотивовані на досягнення успіху (надмірно і помірно високі рівні мотивації); 44 \% студентів - середній рівень мотивації та 4 \% студентів проявляють низьку мотивацію для досягнення успіху. Виходячи із результатів анкетування, можна стверджувати, що для формування у студентів мотивації досягнення на успіх у навчальній діяльності необхідно шляхом навчання способів поведінки, типових для людини з високорозвинутою мотивацією досягнення, що передбачають особисту відповідальність за успіх справи.

Висновки. Мотивація навчальної діяльності студентів - складний та багаторівневий процес, вивчення якого є важливим компонентом оптимізації підготовки майбутніх професійних лікарів. У ході проведення анкетування було виділено основні мотиви (професійні), які розкривають сутність навчальної мотивації студентів медичного факультету, як об’ єкта діагностування. Результати обробки анкет показали, що резерви з мотивування студентів до навчання $є$ різноманітними та вимагають обгрунтованих організаційних та наполегливих управлінських зусиль професорсько-викладацького складу для компетентного впливу на підвищення навчальної мотивації студентів. Варто зазначити, що отримані результати анкетування можуть бути використані в подальших дослідженнях щодо вдосконалення шляхів, методів та засобів організації навчально-виховного процесу у вузах.

5. Розанова В. А. Психология управления / В. А. Розанова. - М., 1999. - С.105-106.

6. Бадмаева Н. Ц. Влияние мотивационного фактора на развитие умственных способностей : монография / Н. Ц. Бадмаева. - Улан-Удэ, 2004. - С.151-154.

7. Плис М. А. Факторы формирования у студентов мотивации к обучению / М. А. Плис // Актуальні проблеми державного управління, педагогіки та психології. 2012. - № 9. - С. 300-305. 